\title{
Prospects for the use of fermentation technology in meat products
}

\author{
National University of Food Technologies, Kyiv, Ukraine
}

\section{Oleg Galenko}

\begin{abstract}
The topicality of the work is to justify the choice of low-grade meat raw material as a matrix for tying together calcium ions. The rumen of cattle, leaf mussels, semifinished and ready-minced sausages are studied.

It was determined rational $\mathrm{pH}$ parameters, temperature, duration, duty of water curve of environment and amount of enzyme preparation for efficient proteolysis on model systems.

By means of complete factorial test, mathematical model of dependence of length and temperature of proteolysis is developed. The indicator of amino nitrogen content in the received hydrolyzate of paunch of cattle was selected as the parameter of optimization. The study is conducted and the confirmation of the data in model environments during proteolysis of by-products of the second category (cow tripe) is received.

The required amount of enzyme economically feasible for efficient proteolysis in technological processes $-0,01 \%$ by weight of raw materials. Settings rational $\mathrm{pH}$ parameters $-5,0-7,5$, temperature $-25-40{ }^{\circ} \mathrm{C}$, amount of enzyme preparation for efficient proteolysis on model systems $-3 \mathrm{~h}$., duty of water curve of environment $1: 2$.

The results are suggested to use in meat products industry of special food gerodietetic. The development enables to reduce price of finished product, enrich it with micronutrients and improve it digestion by the human body.

The results of the recommended meat products in special food - Gerontologic. Development reduces the cost of finished products, enriches its micronutrients and improves its absorption by the human body.
\end{abstract}

Key words: meat, gerodietetic, tripe, proteolysis enzyme, collagenase.

Corresponding author: Oleg Galenko

E-mail: galen@i.ua

DOI: $10.24263 /$ RES-2019-6

\section{Introduction}

Disruption of the normal flow of processes of natural reproduction of population led to a decrease in the proportion of people whose age is under working age, to growth in working age and older than working age, which generally resulted in an increase in population pressure on the working age population. Overall mortality exceeds twice the corresponding rates of EU countries, the mortality rate of working age people exceeds in 2-3 times. 
So, ensuring and strengthening of population health, extending the period of active longevity, prolonging life expectancy, focusing on health as a social value can provide citizen with competitiveness in the labor market, professional longevity, welfare and as a result - improvement of life quality, strengthening of human potential, preservation of the gene pool of the people, improvement of the demographic situation in the country. The economic business costs for employment potential recovery from disability will reduce. However, it is important to form an understanding of individual responsibility for health.

Meat is the most important food product that provides human with essential, highquality and full value animal protein. One of the most important tasks of providing humanity with food is to increase production of meat and meat products to satisfy the needs of population. It is important not only to increase the total production of meat products, but also provide their maximum production of each ton of raw materials, improve the quality, nutritional value and commodity indices extend the range. Solving this problem requires work to create precocious meat breeds of cattle, rational use of meat and products of animal slaughter, the intensification of technological processes, creating meat analogy and the use of plant and microbial proteins.

It is known that to achieve high economic efficiency of processing by-products it is necessary to strive to maximize their use in cost-effective high-quality manufactured meat products, such as sausages and smoked sausages that are most in demand and more stable to storage. One of the most promising ways to achieve maximum production efficiency, improve and stabilize the quality of sausages is the production with a minimum cost. This is achieved through the most rational use of raw materials, first of all, through the usage of muscle protein, the wide use of secondary raw materials (scrap, offal, protein components of plant and animal origin).

By-products of the second category have a full set of essential amino acids. As it is shown in Table 1, cattle rumen is the most significant source of collagen, which has more than half of connective tissue proteins (contains 61,3\% of collagen of the total protein). Collagens form insoluble filaments (fibrils), which are the part of extracellular matrix and connective tissues.

Table 1

Chemical composition of beef by-products of the second category

\begin{tabular}{|l|c|c|c|c|}
\hline \multirow{2}{*}{ By-products } & \multicolumn{4}{|c|}{ Protein content, \% } \\
\cline { 2 - 5 } & total protein & collagen & salt-soluble & collagen of the protein \\
\hline Lips & $20,3 \pm 2,9$ & $13,4 \pm 1,4$ & $0,6 \pm 0,1$ & 66,0 \\
\hline Abomasum & $14,4 \pm 1,5$ & $5,9 \pm 0,2$ & $0,7 \pm 0,2$ & 41,2 \\
\hline Cattle rumen & $17,1 \pm 1,8$ & $10,5 \pm 0,8$ & $0,8 \pm 0,1$ & 61,2 \\
\hline Gullet meat & $16,3 \pm 1,4$ & $5,7 \pm 0,7$ & $1,9 \pm 0,1$ & 34,7 \\
\hline Spleen & $16,4 \pm 0,6$ & $1,9 \pm 0,4$ & $7,9 \pm 0,2$ & 11,3 \\
\hline Lungs & $16,1 \pm 1,0$ & $4,3 \pm 0,5$ & $4,4 \pm 0,1$ & 26,3 \\
\hline Trachea & $15,6 \pm 0,8$ & $6,2 \pm 0,9$ & - & 39,5 \\
\hline Head' meat & $18,8 \pm 0,4$ & $6,5 \pm 0,2$ & - & 36,3 \\
\hline Ears & $25,2 \pm 0,1$ & $17,9 \pm 0,1$ & - & 71,0 \\
\hline
\end{tabular}




\section{Materials and methods}

The rumen of cattle, leaf mussels, semi-finished and ready-minced sausages are studied.

Rumen of cattle receiving from healthy adult cattle from private farms. Leaf mussels were collected from private mussel farms in the Black Sea in the waters of Kerch. All parties were selected toxicological and radiological control center for evaluating the quality and safety of food materials. Semi-finished and ready-minced sausages produced in the scientific laboratory of the university.

It was determined rational $\mathrm{pH}$ parameters, temperature, duration, duty of water curve of environment and amount of enzyme preparation for efficient proteolysis on model systems.

Processing of the experimental data was carried out statistical modeling using Excel spreadsheet and problem-oriented mathematical calculations package Math Cad. A mathematical model of comprehensive quality index calculated by the method of numerical characteristics of the object, based on the law of additivity, which can be used to construct a model of food quality designation. The results of any measurements always contain some error.

The experimental results were treated by mathematical statistics, given the repetition of experiments, average values of the studied parameters, the rate of approximation.

\section{Results and discussion}

Cleaned rumens were cooled in the tub with running water and kept for 20-30 min on frames with hooks. At the end of the process rumens were chopped in the meat mincer with a grating diameter of 2-3 mm. Salt was added at a rate of $3 \mathrm{~kg}$ per $100 \mathrm{~kg}$ of raw material (3\%) and dimethyl sulfoxide $-200 \mathrm{ml}$ per $100 \mathrm{~kg}$ of rumen $(0,25 \%)$.

The ready substance is mixed thoroughly for 3-4 minutes and placed in a refrigerator $\left(2-4{ }^{\circ} \mathrm{C}\right)$. Filling was prepared after 24 hours of storage. Before cooking the filling, we poured liquid that was released from the rumen softened in salt mixture.

Before salting, beef was chopped in the meat mincer with a grilles diameter of 16-22 mm, and for pork $-8-12 \mathrm{~mm}$. Meat was` salted and kept at a temperature of 2$4{ }^{\circ} \mathrm{C}$ overnight. During this process the raw was stored in a container with a layer of $15 \mathrm{~cm}$.

Enzymatic treatment leads to destructive changes of raw materials, increase of number of hydrophilic centers, increase of functional groups as a result of rupture of polypeptide chains, which further will be more accessible for reactions including calcium. However, our goal was not a complete hydrolyzate of protein molecules to amino acids, we tried to achieve only partial hydrolysis to increase the number of free functional groups, including those that are capable of binding calcium (Figure 1). 


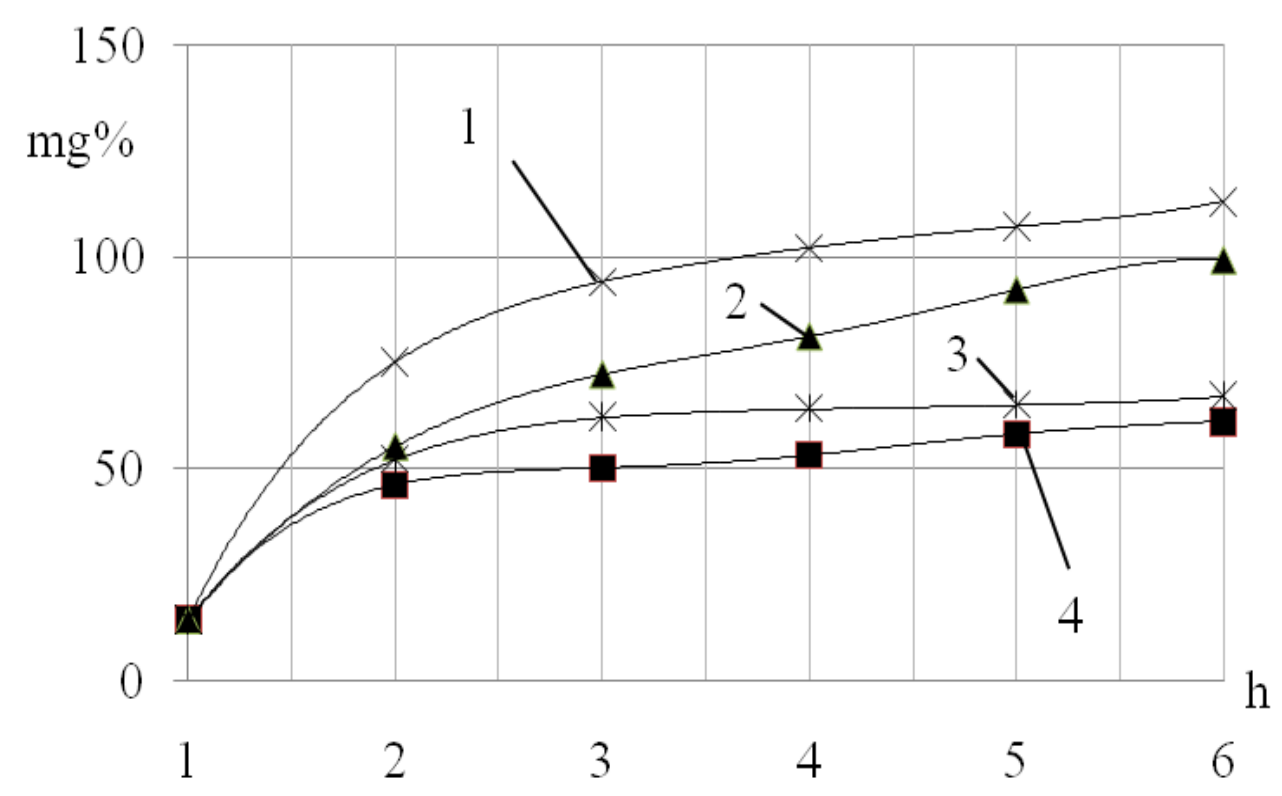

Figure 1. Diagram of accumulation of amino nitrogen in the processing of the rumen of cattle, depending on the ambient temperature: 1 - treatment at $2{ }^{\circ} \mathrm{C}$;

2 - treatment at $12{ }^{\circ} \mathrm{C} ; 3$ - treatment at $37^{\circ} \mathrm{C} ; 4$ - treatment at $50{ }^{\circ} \mathrm{C}(\mathrm{pH}-7,0)$.

Processing of cattle rumen was held by $0,05 \%$ solution of the enzyme by weight of raw materials at temperature regimes: $2{ }^{\circ} \mathrm{C}$ (cold chamber), $12{ }^{\circ} \mathrm{C}$ (in meat processing plants in the shops), $37{ }^{\circ} \mathrm{C}$ (norm of body temperature) and $50{ }^{\circ} \mathrm{C}$ (thermostat) for 5 hours.

Proteolysis of protein of collagen containing tissue is observed in all modes, as evidenced by the accumulation of amino nitrogen. The highest rate of proteolysis of proteins is observed during the first time, as shown by angle curves from the second processing time it is reduced. The largest number of amino nitrogen was observed at $37{ }^{\circ} \mathrm{C}$ in each period, minimum - at $2{ }^{\circ} \mathrm{C}$. So, after 2 hours of fermentation amount of amino nitrogen in samples that were treated at $37{ }^{\circ} \mathrm{C}$ increased by 5.8 times at $12{ }^{\circ} \mathrm{C}-$ 4.5 times, at $2{ }^{\circ} \mathrm{C}-3$ times, further the rate of decay of proteins to peptides and amino acids gradually decreased. Thus, the most effective fermentation temperature is $37^{\circ} \mathrm{C}$.

In conditions of production the support of $37{ }^{\circ} \mathrm{C}$ entails additional costs for equipment and energy, which is undesirable in the development of new technologies. Also such temperature creates optimal conditions for microbial growth. Therefore, temperature $12{ }^{\circ} \mathrm{C}$ is more suitable, which is chosen for further studies because it is constantly maintained at a meat processing enterprises in manufacturing plants, but also increased the concentration of enzyme to $0,1 \%$.

Salted beef was minced in meat mincer with hole diameter of 2-3 $\mathrm{mm}$ before cooking. Preparation and processing of minced were performed in mixer. Minced meat and rumen were mixed with spices and auxiliary materials for $23 \mathrm{~min}$. Six batches of minced meat were prepared under the first variant, one batch under the second variant to assess the influence of the composition of minced meat with rumen on the quality of sausages (Table 2).

Pork bellies were filled with minced meat of each batch, twisted like a long loaf of $20-25 \mathrm{~cm}$ long. After ling loaf sinking at temperatures above $8{ }^{\circ} \mathrm{C}$ for $2-4$ hours it 
was boiled at $80 \pm 5^{\circ} \mathrm{C}$ for $60 \mathrm{~min}$. to achieve the temperature inside the long loaf $75 \pm 2$

${ }^{\circ} \mathrm{C}$. After, the sausage was cooled at a temperature of $12 \pm 2{ }^{\circ} \mathrm{C}$.

Spices and support materials are the following components $(\mathrm{g} / 100 \mathrm{~kg}$, raw): sodium nitrite (solution) - 5; sugar sand - 100; ground black pepper - 100; allspice powder - 100; coriander - 150; fresh garlic - 200 .

Table 2

Composition of cooked sausages

\begin{tabular}{|c|c|c|c|c|c|c|c|}
\hline \multirow{2}{*}{ Ingredients, \% } & \multicolumn{7}{|c|}{ Variant } \\
\cline { 2 - 9 } & \multicolumn{7}{|c|}{1} \\
\cline { 2 - 9 } & $\mathrm{A}$ & $\mathrm{B}$ & $\mathrm{C}$ & $\mathrm{D}$ & $\mathrm{E}$ & $\mathrm{F}$ & - \\
\hline First class beef & 60 & 60 & 60 & 60 & 60 & 60 & 60 \\
\hline Half-fat, veiny pork & 35 & 33 & 30 & 28 & 22 & 20 & 30 \\
\hline Cattle rumen & 3 & 5 & 7 & 8 & 9 & 11 & 7 \\
\hline Starch of flour & 2 & 2 & 3 & 4 & 4 & 4 & 3 \\
\hline
\end{tabular}

Samples of each batch were selected and analyzed under the established rules to (5-7) at the Department of Technology of meat and meat products of National University of Food Technologies determine the organoleptic and physico-chemical parameters and yield. Table 3 and 4 show that batches A, B, C and D meet the requires of cooked sausages. In terms of profitability of used raw and the possibility of using the optimal quantity of rumen batch formulation $\mathrm{C}$ and $\mathrm{D}$ can be used.

Studies showed that the shelf life of such a sausage is no more than 8 days at a temperature not higher than $12{ }^{\circ} \mathrm{C}$ and a relative humidity of $75-78 \%$. The moisture content in the finished product $57-60 \%$, salt $-3 \%$. The output of finished products (sausages) to substance of unsalted raw is $115-128 \%$.

\section{Conclusion}

1. The use of the rumen in the production of cooked sausages is the best way to use rumen collagen and dimethyl sulfoxide $+\mathrm{NaCl}$ may serve as an inhibitory agent.

2. It is shown that the effective concentration of nutritive collagenase during proteolysis of the cattle rumen is $-0.1 \%$ by weight of raw material.

3 . It is founded that the maximum proteolytic activity of enzyme preparation nutritive collagenase at $\mathrm{pH}-7,0$; duty water curve $-1: 1$; temperature $-12{ }^{\circ} \mathrm{C}$, proteolysis duration -3 hours.

\section{References}

1. Jochen Weiss, Monika Gibis, Valerie Schuh, Hanna Salminen, (2010), Advances in ingredient and processing systems for meat and meat products, Meat Science, 86(1), pp. 196-213. 
2. Melnyk O., Radzievska I., Galenko O., Peshuk L. (2018) Investigation of vegetable oils to oxidative degradation of varying degrees of saturation with tocopherol, Carpathian journal of food science and technology, 10(3), p. 164171.

3. Alison J. McAfee, Emeir M. McSorley, Geraldine J. Cuskelly, Bruce W. Moss, Julie M.W. Wallace, Maxine P. Bonham, Anna M. Fearon, (2010), Red meat consumption: An overview of the risks and benefits, Meat Science, 84(1), pp. 113.

4. Kenneth W. McMillin, (2008), Where is MAP Going? A review and future potential of modified atmosphere packaging for meat, Meat Science, 80(1), pp. 43-65.

5. Kandeepan G., Anjaneyulu A.S.R., Kondaiah N., Mendiratta S.K., Lakshmanan V. (2009), Effect of age and gender on the processing characteristics of buffalo meat, Meat Science, 83(1), pp. 10-14

6. Hutchison C.L., Mulley R.C., Wiklund E., Flesch J.S. (2012), Effect of concentrate feeding on instrumental meat quality and sensory characteristics of fallow deer venison, Meat Science, 90(3), pp. 801-806.

7. Peshuk L.V., Galenko O.O., Budnik N.V. (2014), Use of collagenase in technology gerodietetic products, Journal of food and packing science, technique and technologiesm, II(3), pp. 8-11.

8. Radzievska I., Melnyk O., Galenko O. (2018), Two-stage technology for palm oil fractionation for production of cocoa butter substitutes, Nauka innov., 14(1), pp. $40-49$. 